\title{
Insulin Receptor Substrate 2
}

National Cancer Institute

\section{Source}

National Cancer Institute. Insulin Receptor Substrate 2. NCI Thesaurus. Code C28475.

Insulin receptor substrate 2 (1338 aa, $\sim 137 \mathrm{kDa}$ ) is encoded by the human IRS2 gene.

This protein is involved in insulin-dependent signal transduction. 